\title{
Path Analysis on Life Course Factors Affecting Overweight and Obesity in Children Aged 2 to 5 Years Old in Surakarta
}

\author{
Uyunun Nudhira'), Cri SP Wekadigunawan²), Bhisma Murti1) \\ ${ }^{1)}$ Masters Program in Public Health, Universitas Sebelas Maret \\ 2) Faculty of Medicine, Universitas Sebelas Maret
}

\begin{abstract}
Background: Globally, prevalence of obesity in children under 5 years old has been increasing from 32 million in 1990 to 42 million in 2014. Indonesia ranks highest in the number of obesity cases in South East Asia with prevalence of 11.5\% in 2013. However, child overweight and obesity have not been the focus of health problems in Indonesia. Early intervention and prevention of child obesity can reduce long-term risk of chronic diseases in adulthood. This study aimed to analyze the life course factors affecting overweight and obesity in children aged 2 to 5 years old in Surakarta.

Subjects and Method: This was an analytic observational study with case control design. The study was conducted in 5 community health centers, Surakarta, from September to October, 2017. A total sample of 150 children aged 2 to 5 years old was selected using fixed disease sampling. The dependent variable was overweight or obesity. The independent variables were nutrition intake, exclusive breastfeeding, starting age of complementary feeding, physical activity, birthweight, age of gestation, sectio cesarea labor, maternal body mass index, and maternal job. Physical activity data was measured using Pre PAQ questionnaire. Other data were collected using a set of questionnaire and maternal and child health monitoring book. The data were analyzed by path analysis.

Results: Overweight and obesity in children aged 2 to 5 years old were positively affected by over nutrition intake $(\mathrm{b}=1.9 ; 95 \% \mathrm{CI}=0.15$ to $3.60 ; \mathrm{p}=0.033)$, high maternal body mass index $(\mathrm{b}=2.0$; $95 \% \mathrm{CI}=0.51$ to $3.42 ; \mathrm{p}=0.008)$, and sectio cesarean birth $(\mathrm{b}=2.1 ; 95 \% \mathrm{CI}=0.56$ to 3.73 ; $\mathrm{p}=0.008)$. Overweight and obesity in children aged 2 to 5 years old were negatively affected by normal birthweight $(b=-2.2 ; 95 \% \mathrm{CI}=-4.28$ to $-0.19 ; \mathrm{p}=0.032)$, exclusive breastfeeding $(\mathrm{b}=-2.0$; $95 \% \mathrm{CI}=-3.60$ to $-0.39 ; \mathrm{p}=0.015)$, timely starting age of complementary feeding $(\mathrm{b}=-1.3 ; 95 \% \mathrm{CI}=$ -2.80 to $0.11 ; \mathrm{p}=0.072)$, and high physical activity $(\mathrm{b}=-3.0 ; 95 \% \mathrm{CI}=-4.63$ to $-1.37 ; \mathrm{p}=0.001)$. Birthweight was positively affected by age of gestation $(b=4.2 ; 95 \% \mathrm{CI}=1.99$ to $6.32 ; \mathrm{p}=0.001)$ and was negatively affected by maternal body mass index $(b=-1.1 ; 95 \% \mathrm{CI}=-2.11$ to $-0.13 ; \mathrm{p}=0.025)$. Exclusive breastfeeding was negatively affected by working outside the house $(\mathrm{b}=-1.4 ; 95 \% \mathrm{CI}=-$ 2.10 to $-0.72 ; \mathrm{p}=0.001$ ).

Conclusion: Overweight and obesity in children aged 2 to 5 years old are positively affected by over nutrition intake, high maternal body mass index, and sectio cesarean birth. Overweight and obesity in children aged 2 to 5 years old are negatively affected by normal birthweight, exclusive breastfeeding, timely starting age of complementary feeding, and high physical activity.
\end{abstract}

Keyword: life course factors, overweight, obesity, path analysis.

\section{Correspondence:}

Uyunun Nudhira. Masters Program in Public Health, Sebelas Maret University, Jl. Ir. Sutami 36 A, Surakarta 57126, Central Java. Email: uyununnudhira14@gmail.com. Mobile: +6285253781714

\section{BACKGROUND}

Nutritional problems in ASIA become doubel burden in which on one side, wasting and stunting is still high, on the other hand obesity is also increasing
(UNICEF, WHO and World Bank, 2014; Black et al., 2013). Currently, all countries in the world are facing problems of epidemiological transition of diseases which are not infectious in both developed 
Journal of Epidemiology and Public Health (2017), 2(3): 267-283

https://doi.org/10.26911/jepublichealth.2017.02.03.08

and developing countries. Risk factors that increase the potential for non-infectious diseases include overweight and obesity (WHO, 2016). As described in NCDs, overweight and obesity cause $55 \%$ of deaths from non-infectious diseases (WHO, 2016b).

Overweight and children under 5 obesity have increased globally from 32 million in 1990 to 41 million by 2014 (WHO, 2016b). All over the world, overweight and obesity in infants and children are predicted to increase to 70 million by 2025 . With the increase in the proportion of obesity cases at different ages, it has become one of the nine targets of the global monitoring program framework for non-infectious diseases (WHO, 2014; Wijnhoven et al., 2016).

The number of overweight and children obesity cases in Asia continues to increase. In 2013, the highest number of overweight and children obesity in Azerbaijan was $13.0 \%$ and the lowest one was at Vannatu (4.6\%). In Southeast Asia, the highest overweight and children obesity is in Indonesia which was $11.5 \%$ and the lowest one was in the Philippines for about 5.0\% (ADB, 2016).

Obesity and its association with various comorbidities have posed a serious threat to the global health (Han, et al., 2017). Obesity is a major cause of cardiovascular disease (Hardy, 2015). Overweight and obesity are the main risks of serious chronic diseases (Labresh, 2016) Overweight and obesity in children increase the risk of death $40-90 \%$ higher in their adulthood than normal children do (Hirko et al., 2015).

Overweight and obesity in childhood lead to morbidity and mortality in adulthood (Redsell et al., 2016). Obesity that continues into adulthood can lead to chronic diseases, such as hypertension, type
2 diabetes, heart disease, certain types of cancer development, insomnia and sleep disorders (Ahima, 2014; Debasis, 2011; Godfrey et al., 2017; Ramírez et al. , 2016). Obesity can cause negative impacts on children's mental and social health, low self-esteem and depression (Small and Aplasca, 2016). Therefore, efforts to prevent overweight and obesity need to be done early (Blake-Lamb et al., 2016). Factors that affect obesity include, genetic history, obese parents, smoking, low and over birth weight, not receiving exclusive breastfeeding and rapid duration, the quality of child's sleep, unbalanced diet which is high in calories and fat, less physical activity, and at a higher level it may be affected by circumstances in communities, environments, and demographic factors (Bam-mann et al., 2014; Poston, 2012). The influence of other factors such as genetic, biological, sociocultural, psychological and environmental factors is a risk factor for obesity (Herman et al., 2014; Isgor et al., 2016).

Early detection of overweight and obesity cases is a way of preventing and reducing risk factors that will occur in the future (Redsell et al., 2016; Weng et al., 2012). Health programs that focus on addressing these nutritional problems are the first thousand days of life nutrition to ensure that children grow well as they progress. Good growth and development in the first 1000 days of life will determine the future child development (Blake-Lamb et al., 2016; Woo Baidal et al., 2016).

Overweight and obesity status are also associated with lifelong epidemiology from gestation to adult children (Bammann et al., 2014). A growing theory explains that the lifelong exposure relationship to adult disease is a life course epidemiology (Green and Popham, 2017; Pérez-escamilla and Kac, 2013). 
Based on Indonesia's 2015 health profile, the classification of energy levels and characteristics is found that the largest overweight and obesity rate in Indonesia is between the ages of 5-12 and $10.2 \%$, of it occurs in various regions both urban and rural. The incidence rate in urban areas is $6.9 \%$ and in rural area id $5.8 \%$ (Ministry of Health, 2015). Obesity in Central Java in 2016 was $1.867(3.1 \%)$ and was included in five major non-infectious diseases (Central Java Provincial Health Office, 2016). The prevalence of overweight and obesity in the age group of 2-5 years was $5.4 \%$ overweight and $1.7 \%$ for obesity. One area with an increased prevalence of overweight and obese children aged 2-5 years was Surakarta district, in 2014, for about $3.7 \%$ increase from the previous year which was only $1.45 \%$ (Surakarta Health Office, 2014).

Although in Surakarta it has not become a major problem but overweight and obesity in children 2-5 years need to get more attention considering the increase of health problems caused by it. A preliminary study conducted at the Surakarta health office shows that 1530 infants were overweight and obese. The purpose of this study is to know the influence of path analysis of factors throughout life on overweight and obesity of children under five in Surakarta.

\footnotetext{
SUBJECTS AND METHOD

1. Study design

This was an analytic observasional study with a case control design, by determining the group which was exposed first and then identifying the cause or risk factors of the disease. The study was conducted at Ngoresan, Gilingan, Stabelan, Nusukan, and Penumping community health centers, Surakarta, Central Java, from September 2 to November 28, 2016.
}

\section{Population and sample}

The target population was Toddlers aged 25 years who live in Surakarta. The source population were underweight (2-5 years old) toddlers living in the area of Ngoresan, Gilingan, Stabelan, Nusukan and Penumping Public Health Centers which were overweight and obese and normal (under-five) toddlers for about 150 subjects with the comparison of 1: 2 . The case group consisted of 50 subjects and the control one consisted of 100 subjects.

The sampling technique used in this study was fixed disease sampling by choosing the subjects based on the data of overweight and obese children and normal children at the public health centers, then the data collection process was conducted at integrated health service. The selection of subjects was done randomly according to the sample size required by the researcher. There were ten variables in this study. The dependent variable is overweight and obesity toddlers. The independent variables were maternal body index, gestational age, cesarean delivery, birth weight, exclusive breastfeeding, breastfeeding feeding age, physical activity, diet, and maternal occupation.

\section{Operational of variables}

Overweight or obese in children under five was define by calculated bodyweight/ body height and compared with Z-score. The measurement scale was continuous, but for the purpose of data analysis, it was transformed into dichotomous, coded o for normoweigth and 1 for overweight/ obesity.

The history of the mother with overweight / obesity was determined based on maternal BMI during pregnancy and recorded in the maternal and child monitoring book. Gestational age was defined as the length of time that begins from the time of ovulation to the birth, the duration of distal birth ( $<37$ weeks), and term delivery 
Journal of Epidemiology and Public Health (2017), 2(3): 267-283

https://doi.org/10.26911/jepublichealth.2017.02.03.08

( $\geq 37$ weeks). Sectio caesarean was defined as the expenditure of conception with an incision on the maternal abdomen.

Exclusive breastfeeding was defined as only breastmilk consumed by infants until the first 6 months of age. The age at complementary feeding was defined as the first age of children introduced with solid foods.

Physical activity was defined as the movement that generates the measured energy with the children which is intermittent and is interrupted by breaks and were measured by the Pre-PAQ questionnaire. The diet pattern includes the type, amount and frequency consumed each day. Maternal occupation was defined an act done to earn wages.

\section{Study instrument}

The data collection used questionnaires and KIA books. The instruments that were tested for reliability were dietary and physical activity questionnaires. Based on the results of the correlation reliability test item-total dietary variables were $r$ count Table 1. The Distribution of study subjects

\begin{tabular}{|c|c|c|c|c|}
\hline \multirow{2}{*}{ Characteristics } & \multicolumn{2}{|c|}{ Obesity (case) } & \multicolumn{2}{|c|}{ Normoweight (control) } \\
\hline & $\mathbf{n}$ & \% & $\mathbf{n}$ & $\%$ \\
\hline \multicolumn{5}{|l|}{ Gender } \\
\hline Male & 26 & 52 & 53 & 53 \\
\hline Female & 24 & 48 & 47 & 47 \\
\hline \multicolumn{5}{|l|}{ Maternal age (year) } \\
\hline$<35$ & 29 & 58 & 72 & 72 \\
\hline$\geq 35$ & 21 & 42 & 28 & 28 \\
\hline \multicolumn{5}{|l|}{ Children age (months) } \\
\hline$<36$ & 19 & 38 & 43 & 43 \\
\hline$\geq 36$ & 31 & 62 & 57 & 57 \\
\hline \multicolumn{5}{|l|}{ Number of children } \\
\hline$<3$ & 42 & 84 & 74 & 74 \\
\hline$\geq 3$ & 8 & 16 & 26 & 26 \\
\hline \multicolumn{5}{|l|}{ Maternal education } \\
\hline Low (<Senior high schol) & 10 & 20 & 36 & 36 \\
\hline High ( $\geq$ Senior high school) & 40 & 80 & 64 & 64 \\
\hline \multicolumn{5}{|l|}{ Family Income } \\
\hline$<\operatorname{Rp} 2,000,000$ & 18 & 36 & 53 & 53 \\
\hline$\geq \mathrm{Rp} 2, \mathrm{OOO}, \mathrm{OOO}$ & 32 & 64 & 47 & 47 \\
\hline
\end{tabular}

$\geq 0.22$ and Cronbach Alpha $\geq 0.77$, on the physical activity variables $\mathrm{r}$ arithmetic $\geq 0.21$ and Cronbach Alpha $\geq 0.91$, so that all questions/items were stated as reliable.

\section{Data analysis}

This study used path analysis. This analysis can calculate the magnitude of the direct and indirect effects of any independent variable on the dependent variable. Steps to perform path analysis included model specifications, model identification, model conformity, parameter estimation, and model respesification.

\section{Research ethics}

The research ethical clearance was obtained from the Research Ethics Committee at Dr. Moewardi Hospital, Surakarta, Central Java, Indonesia. Research ethics included issues such as informed consent, anonimity, confidentiality, and ethical clearance.

\section{RESULTS}

\section{Sample Characteristics}

The characteristics of subjects in this study are presented in Table 1. 
Table 1 shows the characteristics of the study subjects from 150 of them, 26 were male (52\%) and 53 control (53\%). The number of ,others who were $<35$ years old was $29(58 \%)$ cases and $72(72 \%)$ for the control one. There were 31 (62\%) underfive children who were over 36 months. As many as 40 (80\%) mothers had education $\geq$ Senior high school.

\section{Path Analysis}

Figure 1 shows the structural model after estimating data processing using STATA 13 application with SEM (Structural Equation Modeling) program. Path analysis explains the direct and indirect effects of overweight and obesity causes in infants. The degree of freedom (df) = 35 value is over-identified so that path analysis can be done. This study has been in accordance with the sample data shown by the saturation model and also the regression coefficient which is more than zero and statistically significant, so there is no need to re-create the path analysis model.

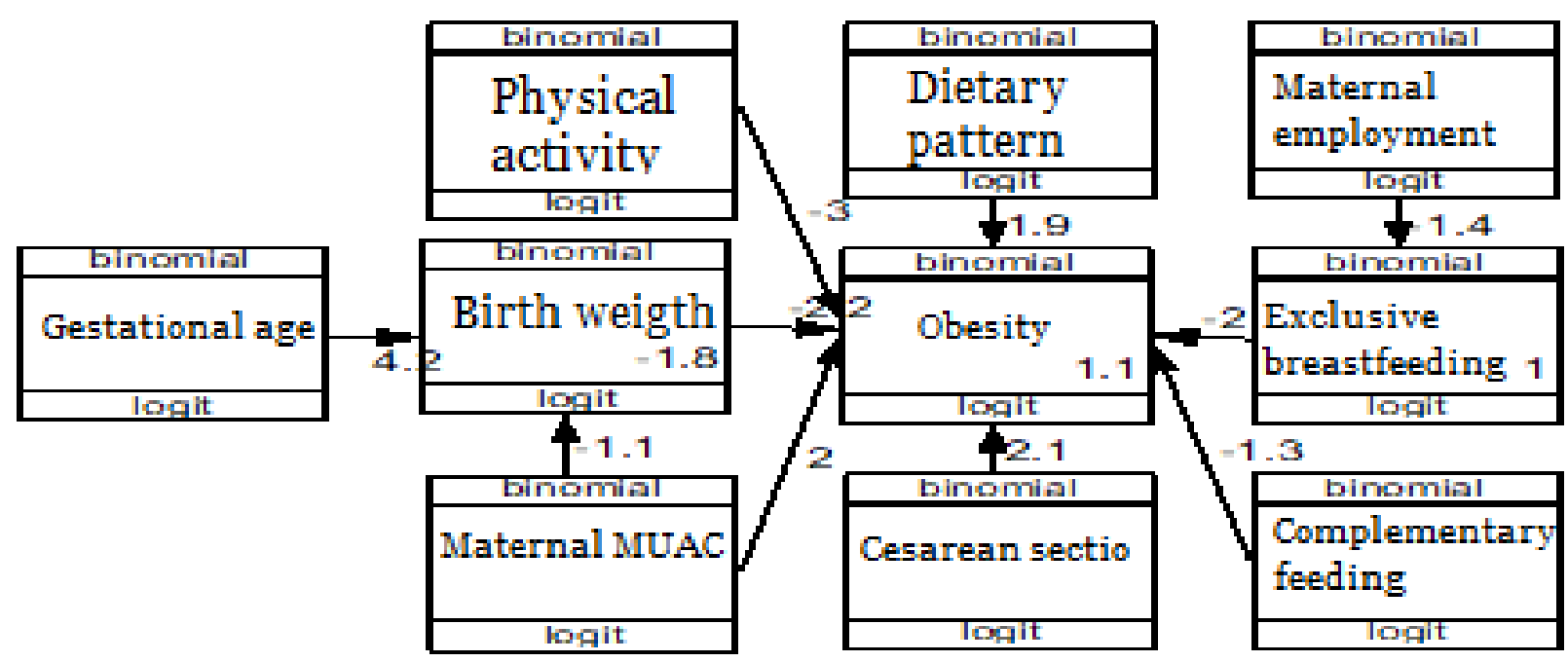

Figure 1. Structural model of path analysis

Table 2 shows that there is an association of Maternal BMI with an overweight increase and obese infant which was statistically significant. Overweight/ obese mothers had overweight and overweight children's obesity scores of 2 units higher than normal body mass index mothers ( $b=2.0 ; 95 \% \mathrm{CI}$ $=0.51$ to $3.42 ; \mathrm{p}=0.008$ ).

There was a relationship between birth weight and the decrease of overweight or obesity in children which was statistically significant. Normal birth weight has overweight logit score and obesity of underweight of 2.2 units lower than underweight children with low birth weight
$(<2,500 \mathrm{~g})(\mathrm{b}=-2.2 ; 95 \% \mathrm{CI}=-4.28$ to $0.19 ; \mathrm{p}=0.032)$.

There was a relationship between a cesarean delivery and the increase of overweight and obesity in children and was statistically significant. Cesarean delivery had overweight and overweight children's obesity scores of 2.1 units higher than mothers with normal delivery $(b=2.1 ; 95 \%$ $\mathrm{CI}=0.56$ to $3.73 ; \mathrm{p}=0.008$ )

There was a relationship between exclusive breastfeeding and a decrease of overweight and obesity in children under five and was stastically significant. Exclusive breastfeeding had an overweight logit score and under-five obesity of 2 units 
Journal of Epidemiology and Public Health (2017), 2(3): 267-283

https://doi.org/10.26911/jepublichealth.2017.02.03.08

lower than toddlers who do not get exclusive breastfeeding $(\mathrm{b}=-2.0 ; 95 \% \mathrm{CI}=-3.60$ to -0.39; $\mathrm{p}=0.015$ ).

There a correlation between age at complementary feeding and the decrease of overweight and obesity in under-five children and was statistically significant. Age at complementary feeding more than 6 months had overweight logit score and childhood obesity of 1.3 units lower than under-five children given breastfeeding MP less than 6 months $(\mathrm{b}=-1.3$; 95\% CI $=$ 2.80 to $0.11 ; \mathrm{p}=0.072$ ).

There was a relationship between physical activity and the decrease of overweight and obesity in under-five children and was stated as statistically significant. Active physical activity had

Table 2. Results of pathway analysis of lifetime overweight and obese factors in children

\begin{tabular}{|c|c|c|c|c|c|c|}
\hline \multirow[b]{2}{*}{$\begin{array}{l}\text { Dependent } \\
\text { Variable }\end{array}$} & & \multirow[b]{2}{*}{ Independent Variable } & \multirow[b]{2}{*}{$\begin{array}{c}\text { Path } \\
\text { Coefficient }\end{array}$} & \multicolumn{2}{|c|}{$95 \%$ CI } & \multirow[b]{2}{*}{$\mathbf{p}$} \\
\hline & & & & $\begin{array}{r}\text { Lower } \\
\text { Limit }\end{array}$ & $\begin{array}{l}\text { Upper } \\
\text { Limit }\end{array}$ & \\
\hline \multirow{8}{*}{$\begin{array}{l}\text { Direct Effect } \\
\text { Overweight/ } \\
\text { Obesity }\end{array}$} & & & & & & \\
\hline & $\leftarrow$ & $\begin{array}{l}\text { Mothers body mass } \\
\text { index }\end{array}$ & 2.0 & 0.51 & 3.42 & 0.008 \\
\hline & $\leftarrow$ & Birth weight & -2.2 & -4.28 & -0.19 & 0.032 \\
\hline & $\leftarrow$ & Caesarean section & 2.1 & 0.56 & 3.73 & 0.008 \\
\hline & & Exclusive breastfeeding & -2.0 & -3.60 & -0.39 & 0.015 \\
\hline & & $\begin{array}{l}\text { The first age at } \\
\text { complementary feeding }\end{array}$ & -1.3 & -2.80 & 0.11 & 0.072 \\
\hline & & Physical activity & -3.0 & -4.63 & -1.37 & 0.001 \\
\hline & $\leftarrow$ & Dietary pattern & 1.9 & 0.15 & 3.60 & 0.033 \\
\hline \multicolumn{7}{|l|}{ Indirect Effect } \\
\hline \multirow[t]{2}{*}{ Birth weight } & $\leftarrow$ & Gestational age & 4.2 & 1.99 & 6.32 & 0.001 \\
\hline & & $\begin{array}{l}\text { Mothers body mass } \\
\text { index }\end{array}$ & -1.1 & -2.11 & -0.13 & 0.025 \\
\hline \multicolumn{2}{|l|}{ Log Likelihood= } & Occupation & -1.4 & -2.10 & -0.72 & 0.001 \\
\hline
\end{tabular}

There was a statistically significant relationship between maternal body mass index and weight loss. Mothers with normal body mass index had a lower birth weight logit score of 1.1 units lower than that of overweight mothers / obese $(b=-1.1 ; 95 \%$ $\mathrm{CI}=-2.11$ to $-0.13 ; \mathrm{p}=0.025)$. overweight logit score and underweight obesity of 3 units lower than under-five children with inactive physical activity $(\mathrm{b}=$ $-3.0 ; 95 \% \mathrm{CI}=-4.63$ to $-1.37 ; \mathrm{p}=0.001$ ).

There was a significant relationship between diet with overweight and underweight obesity. A diet high in carbohydrates and fats had overweight and overweight children's obesity scores of 2 units higher than low-carbohydrate and fat diets $(\mathrm{b}=$ 1.9; $95 \% \mathrm{CI}=0.15$ to $3.60 ; \mathrm{p}=0.033$ ).

There was a statistically significant relationship between gestational age and birth weight gain. Gestational age $(<37$ weeks) had a low birth weight logit score of 4.2 units higher than gestational age $(\geq 37$ weeks) $(\mathrm{b}=4.2 ; 95 \% \mathrm{CI}=1.99$ to $6.32 ; \mathrm{p}=$ $0.001)$. 


\section{DISCUSSION}

1. The effect of maternal body mass index (BMI) with overwight or obesity in children under five

The result of this study showed that there was a positive and significant effect between maternal body mass index and overweight and obesity in children. Mothers with overweight/obesity were more likely to have overweight/obesity infants compared to mothers with normal weight.

Obesity in pregnant women is associated with excessive amounts of nutrients to the fetus in the form of fatty acids, increased fetal blood pressure and the accumulation of babies' body fat. The enhancement of body weight and body fat will increase the risk of obesity to children in the future. Pregnant women with obesity lead to trans-generational thus increasing the risk of disease in their babies (Koletzko et al., 2014).

The overweight during pregnancy will continue until postpartum. The evidencebased cycle of heredity suggests that newborns from overweight/obese pregnancies are more likely to store excessive body fat from the earliest period in life (Pérez-escamilla and Kac, 2013).

The history of obese parents increased the risk of overweight in children by 1.38 times compared to parents with normal body weight (Mamun, et al., 2014).

The study of Bammann et al. (2014) found that parental body weight before high pregnancy was associated with obesity in children by 1.02 times than mothers with normal body weight. Children with obese parents have 10.25 times risk to be obese and 3.03 times to have metabolic syndrome compared with parents without obesity (Han et al., 2015).

\section{The effect of birthweight with overweight or obesity in children under five}

The result of this study showed that there was a negative and significant effect between birthweight with overweight and obesity in toddlers. Babies with normal birthweight decrease the risk of overweight/ obesity in toddlers compared to babies with low birthweight.

Low birth weight was associated with increased coronary heart disease, stroke, hypertension, obesity, insulin resistance and type 2 diabetes. The association is considered to be a consequence from the development of different genotypical plasticity in both physiological and environmental morphologies during the development (Barker, 2004; Robinson et al., 2015).

Low birthweight infants have higher plasma levels than normal-weight infants. The enhancement of leptin and the fat mass ratio are also associated with nutrient intake during childhood resulting in the enhancement of leptin production by body fat units. In low birth-weight children, the leptin levels increase with the growth rate in childhood, therefore, the chidlren will have a higher risk of overweight and obesity (Jornayvaz et al., 2016).

A study conducted by Yang and Huffman (2013) shows that birth weight less than 2,500 $\mathrm{g}$ has a risk of metabolic syndrome and has central obesity in adulthood, compared to normal birthweight. Other studies explain that children with low birth weight and low physical activity showed 5.18 times more likely to become obese (Qiao et al., 2017).

\section{The effect of sectio cesarean birth with overweight or obesity in children under five}

The result showed that section cesarean birth has positive effect on overweight/ obesity in toddlers which is statistically 
significant. Cesarean section increased the risk of overweight/obesity in toddlers. The intestinal flora of children born from cesarean birth has low levels of bifidobacteria. In children who born from cesarean section, there is lack of good bacteria from mothers found in birth canal, while the enhancement of bad bacteria can harm the child's immune system, this affects the child's susceptibility to overweight and obesity (Sutharsan et al., 2015). The exposure of gut microbiota in children with cesarean delivery section can increase the potential of biological mechanisms of obesity in the development of infants and children (Kuhle, et al., 2015).

The results of a study on pre-school children aged 3-6 years old, $67.3 \%$ have a history of sectio cesarean birth and $15.7 \%$ are obese. Cesarean delivery increases overweight by 1.7 times and obesity by 1.29 times than normal-born children (Rutayisire et al., 2016).

The study of Pluymen et al. (2016) suggests that 236 or $8.9 \%$ of children born from cesarean section had a 1.52 times higher risk of overweight and obesity than children with prevaginam delivery. Similar study also explained that $70 \%$ of children with sectio cesarean birth have 1.49 times higher risk of obesity than children with normal birth delivery (Flemming et al., 2013).

4. The effect of exclusive breastfeeding with overweight or obesity in children under five

The result showed that exclusive breastfeeding has an effect on overweight/obesity in toddlers which is statistically significant.

Infants with formula milk as the food sources have a higher and longer insulin response than breast-fed children, therefore, it stimulates more fat tissue deposition and resulting in weight gain. Breast-fed children have the ability to regulate the body's internal energy response in recognizing satiety rather than formula-fed children (Binns et al., 2016; Martin et al., 2017). the concentration of leptin (a hormone that works to inhibit appetite and regulate fat in the body) was found with a more balanced concentration in children who were breastfed rather than formula-fed (Daniels et al., 2015).

Non-exclusive breastfeeding causes obesity of $29.9 \%$ higher than exclusive breastfeeding up to 2 years old. In addition, infants who are not breastfed have risk of type 2 diabetes mellitus(Ramírez et al., 2016).

Giving exclusive breastfeeding for less than six months increases the risk of obesity than giving exclusive breastfeeding for more than six months (Daniels et al., 2015; Woo Baidal et al., 2016). Infants with formula milk before 4 months old will increase the risk of obesity in toddlers after 3 years old (Bammann et al., 2014). Breastfeeding is a way of protecting children from obesity risk factors later in life, especially breastfeeding in the first year of life (Weng et al., 2014).

5. The effect of first age at complementary feeding with overweight or obesity in children under five

The result of this study showed that the timely starting age of complementary feeding has an effect on overweight/obesity in toddlers which is statistically significant. Infants with first age of complementary food more than 6 months decrease the risk for overweight/obesity in toddlers.

Exclusive breastfeeding and timely introduction of complementary foods is a prevention of obesity in the future. Complementary foods and high protein intake from an early age was associated with the enhancement of fat mass and obesity in adulthood (Yang and Huffman, 2013). 
Based on a study by Zheng et al. (2015), from 40,510 children, 3.18\% have excess body weight and $64.8 \%$ were given complementary foods before 3 months old. Complementary feeding before the age of 3 months is associated to the risk enhancement by $11 \%$ for overweight or 1.11 times higher risk for overweight/obesity or increased $\mathrm{z}$-score than complementary feeding at 6 months old.

Research with systematic review and meta-analysis showed an association between complementary feeding under 4 months old, including 4-6 months old increase the risk of overweight with a relative risk of 1.18 and obesity with a relative risk of 1.33 higher for the overweight and obese in toddlers compared to complementary feeding at 6 months old (Wang et al., 2017).

\section{The effect of physical activity with overweight or obesity in children under five}

The result of this study showed that children with high physical activities decreased the risk of obesity (negative relationship). The result was statistically significant so that the findings are influential and reliable.

Physical activity is needed in burning the calories in the body. Excessive energy intake and not balanced by adequate physical activity will increase the risk for overweight (Colley et al., 2013). The standard practice of recommended physical activity in toddlers is not too heavy but encourages the children to always actively move, as an intervention and reduce the risk of daily habits of children who are lazy to move, therefore, they will be easily to have overweight or obesity (Howie et al., 2014).

A study by Laurson et al. (2014) explained about weight gain of children who follow the physical activity guidelines, in which children who rarely follow physical activities are 3.1 times more likely in boys and 2.5 times in girls to have overweight and obese than children who regularly follow physical activity guidelines. Other study explained that physical activity in children for less than 1 hour increase overweight and obesity in children by 5.69 times greater than in children who perform physical activity more than 1 hour per day (Zamzani, et al., 2016).

\section{The effect of dietary pattern with overweight/obesity}

The result of this study showed that a diet high in fats and carbohydrates increased energy intake which will further impact on obesity with positive relationships which is statistically significant so that these findings are reliable.

Obesity is caused by an imbalance between the amount of energy that enters and the needs of the body for various biological functions such as physical growth, development, activity, health maintenance. If this condition persists continuously (positive energy balance) in longterm period, then it can lead to obesity (Ahima, 2014; Burton-jeangros et al., 2015; Laurson et al., 2014).

Obesity in the early period of life is influenced by the promotion of dietary habit and healthy eating habits, sedentary and physical activity. Increased prevalence of adipocytes can be known in an early life, family and environmental parenting will increase the chances of children to become obese since early stage. The implementation of the dietary habit and healthy living in children is an early intervention for the occurrence of obesity (Campbell et al., 2016).

Studies show that high-carbohydrate and fat dietary compounds have higher risk of obesity by 1.18 times than low-fat diets and carbohydrate consumption patterns, 
Journal of Epidemiology and Public Health (2017), 2(3): 267-283

https://doi.org/10.26911/jepublichealth.2017.02.03.08

balanced by lack of physical activity, and daily habits that can lead to obesity such as watching TV and playing games (Choukem et al., 2017).

Family habits with wrong dietary habit such as, family modeling, lack of nutritional knowledge, eating time, giving food as a gift, affordability and constraints of good food access and environmental factors also affect children's dietary habit and increase food intake, such as on food availability, advertising, socio-cultural influences and babysitters. All these factors can be the cause of obesity in children associated with dietary habit (Paes, et al., 2015).

\section{The effect of maternal gestational age with overweight or obesity through birthweight}

The result of this study showed that mothers with gestational age $(<37$ weeks) had an effect on overweight/obesity of children through birthweight. Mothers with less gestational age increase the risk of low birthweight, which furthermore becomes more risky for overweight / obesity in infants.

Pre-term gestational age (premature) is a very important perinatal and public health issue, not only because of high rates of neonatal morbidity and mortality and low birth weight, but also an impact on quality throughout the life of the population (Bronstein, 2016; Calkins, et al., 2011).

Premature birth is associated with changes in nutritional status and and the need for normal weight return. Births with very low birthweight, metabolic enhancement, combined with dietary habit, perspectives on nutritional improvement, childhood eating habits, environmental and cultural social determinants, increase the risk in this population. A variety of factors increase the risk of nutritional status to become overweight and chronic illness to the psychological risks caused by premature (Andrade et al., 2015).

A study by McDonald et al. (2010) using systematic review and meta-analysis in developing countries shows that gestational age has an effect on low birthweight and overweight/obesity. Lower gestational age with low birth weight $(<2,500 \mathrm{~g})$ was found to be the highest in women with overweight and obesity, with a relative risk of 1.30 times higher than normal mothers. Overweight and maternal obesity also increases the risk for premature birth (37 weeks) due to medical indications with a relative risk of 1.24 times higher. The highest incidence rate in developing countries with a relative risk of 0.58 higher than developed countries.

\section{The effect of maternal BMI with overweight/ obesty through birth- weight}

The result of this study showed that mothers with overweight/obesity increase the risk of low birthweight which continued to be more risky for overweight/obesity, and it is statistically significant.

Obese mothers significantly modified bolus gene expression associated with neutral lipid transport and storage. Increased regulation of CGI-58, regulator of TG hydrolysis system, contributes to intracellular lipid turnover in placenta of obese women, and it is strictly regulated by maternal metabolic factors (Hirschmugl et al., 2017).

The function of the placenta can affect fetal adiposity tissue at the primary nutritional level. High plasma levels of certain nutrients of obese mothers are considered important as a nutrient transfer link to the fetus resulting in fat accretion that poses a higher risk of fetal weight or low birthweight, due to differences in the differential bolus transfer nutrition settings 
required for fetal growth (Lewis et al., 2013).

Mothers with obesity are associated with adverse long-term effects on children's health such as an increased risk of low birthweight, obesity, metabolic regulation leading to the enhancement of insulin resistance, hypertension, heart and asthma risk. The complex relationship between maternal and fetal metabolic as well as environmental influences and postpartum lifestyle increases the risk of overweight/ obesity of children from pregnancy to birth (O'Reilly and Reynolds, 2013).

The results of the study in Sweden showed that the risk of preterm delivery increased at less gestational age of overweight and obese mothers, a mother with a body mass index (BMI) of 25 to less than 30 increases the risk by 1.26 times, BMI 30 to less than 35 increases the risk by 1.58 times, BMI 35 to less than 40 increases the risk by 2.1 times and BMI more than 40 increase the risk by 2.99 times. The enhancement of maternal BMI will increase the incidence of premature in toddlers. Spontaneous preterm birth occurs in mothers with BMI 30 and prematurely as a result of medical indications increase in mothers between overweight and obesity (Cnattingius et al., 2013).

10. The effect of maternal employment status with overweight or obesity through exclusive breastfeeding

The result of this study showed that maternal employment status has an effect on overweight and obesity in toddlers through exclusive breastfeeding. Working mothers decrease the risk of exclusive breastfeeding so that leads to overweight/ obesity in children.

Working women is one of the fastest causes of breastfeeding weaning processes, this is due to multidimensional effects such as fatigue, practicality, lack of breastfeeding time, and the intensity of meeting with infants (Rollins et al., 2016).

Mothers who plan to return to work on the day off of less than 6 weeks increase the risk by four times to stop the breastfeeding in an early time, it also deals with maternal psychological stress, uncooperative workplaces and the constraints in giving the breastmilk (Guendelman et al., 2009).

Another study explains that mothers who return to work when the infant is less than 12 weeks reduce exclusive breastfeeding rate by 0.68 times compared to mothers with longer day off (Mirkovic et al., 2014). According to Ogbuanu et al., (2011) mothers with long day off and housewives increase the chances of exclusive breastfeeding in infants compared to mothers with short day off.

A study in Ghana showed that housewives increase exclusive breastfeeding by (84\%) and formal working mothers by (16\%). Housewives (informal employment) provide greater opportunities (91\%) for frequent breastfeeding of more than eight times compared to mothers who work in the formal sector (9\%). Most mothers who work in the formal sector do not bring their babies to work, and do not pump their breast milk, therefore, it increases the risk of problems in breastfeeding (Ward et al., 2013; Binns, 2016; Nkrumah, 2017).

\section{REFERENCE}

Asian Depelopment Bank (ADB) (2016). Key Indicators for Asia and the Pacific 2016. Philippines. ADB. ISBN: 97892-9257-630-1.

Andrade AC, Machado MMT, Kenner C, Lindsay AC (2015). Prematurity, Overweight and Obesity: A Problem That Merits Increased Recognition by 
Journal of Epidemiology and Public Health (2017), 2(3): 267-283

https://doi.org/10.26911/jepublichealth.2017.02.03.08

Healthcare Practitioners and Researchers', Newborn and Infant Nursing Reviews. Elsevier BV, 15(4): 174-176. doi: 10.1053/j.nainr.2015.09.002.

Bammann K, Peplies J, De Henauw S, Hunsberger M, Molnar D, Moreno LA, Tornaritis M, et al. (2014). Early life course risk factors for childhood obesity: The IDEFICS case-control study. PLoS ONE, 9(2): 1-7. doi: 10.1371/journal.pone.0086914.

Barker DJP (2004). The Developmental Origins of Adult Disease. Journal of the American College of Nutrition, 23 (588S-595S).

Binns C, Lee M, Low WY (2016). The LongTerm Public Health Benefits of Breastfeeding. Asia-Pacific Journal of Public Health, 28(1): 7-14. doi: 10.1177/1010539515624964.

Black RE, Victora CG, Walker SP, Bhutta ZA, Christian P, De Onis M, Ezzati M, et al. (2013). Maternal and child undernutrition and overweight in low-income and middle-income countries. The Lancet, 382(9890): 427451. doi: 10.1016/So140-6736(13)60937-X.

Blake-Lamb TL, Locks LM, Perkins ME, Woo Baidal JA, Cheng ER, Taveras EM (2016). Interventions for Childhood Obesity in the First 1,00o Days A Systematic Review. American Journal of Preventive Medicine. Elsevier, 5o(6): 780-789. doi:10.1016/j.amepre.2015.11.010.

Bronstein JM (2016). Preterm Birth in the United States. doi: 10.1007/978-3319-32715-0.

Burton-jeangros C, Editors DB, Howe LD, Firestone R, Tilling $\mathrm{K}$ and Lawlor DA. (2015). A Life Course Perspective on Health Trajectories and Transitions. Springer. doi: 10.1007/978-3-31920484-0.
Calkins K, Devaskar SU and Angeles L. (2011). Fetal Origins of Adult Disease. Curr Probl Pediatr Adolesc Health Care, 41(6): 158-176. doi: 10.1016/j.cppeds.2011.01.001.Fetal.

Campbell KJ, Hesketh KD, McNaughton SA, Ball K, McCallum Z, Lynch J, Crawford DA (2016). The extended Infant Feeding, Activity and Nutrition Trial (InFANT Extend) Program: A cluster-randomized controlled trial of an early intervention to prevent childhood obesity Energy balance-related behaviors. BMC Public Health. BMC Public Health, 16(1): 1-10. doi: 10.1186/s12889-016-2836-o.

Choukem SP, Kamdeu-Chedeu J, Leary SD, Mboue-Djieka Y, Nebongo DN, Akazong C, Mapoure YN, et al (2017). Overweight and obesity in children aged 3-13 years in urban Cameroon: a cross-sectional study of prevalence and association with socio-economic status. BMC Obesity. BMC Obesity, 4(1): 7. doi: 10.1186/s406o8-0170146-4.

Cnattingius S, Villamor E, Johansson S, Bonamy A-KE, Persson M, Wikström A-K, and Granath F (2013). Maternal Obesity and Risk of Preterm Delivery. Jama, 309(22): 2362. doi: 10.1001/jama.2013.6295.

Colley RC, Garriguet D, Adamo KB, Carson V, Janssen I, Timmons BW, and Tremblay MS (2013). Physical activity and sedentary behavior during the early years in Canada: a crosssectional study. International Journal of Behavioral Nutrition \& Physical Activity, 10(54-62). doi: 10.1186/1479-5868-10-54.

Daniels LA, Mallan KM, Nicholson JM, Thorpe K, Nambiar S, Mauch CE, Magarey A. (2015). An Early Feeding Practices Intervention for Obesity 
Prevention. Pediatrics, 136(1): e40e49. doi: 10.1542/peds.2014-4108.

Debasis B (2011) Global Perspectives on Childhood Obesity Current Status, Consequences and Prevention. first edit. London UK: Elsevier Inc.

Dinas Kesehatan Provinsi jawa Tengah (2016). Profil Kesehatan Triwulan 2 tahun 2016. Dinas Kesehatan Provinsi Jawa Tengah. 3511351(24)174.

Flemming $\mathrm{K}$, Woolcott CG, Allen AC, Veugelers PJ, Kuhle S (2013). The association between caesarean section and childhood obesity revisited: A cohort study. Archives of Disease in Childhood, 98(7): 526-532. doi: 10.1136/archdischild-2012-303459.

Godfrey KM, Reynolds RM, Prescott SL, Nyirenda M, Jaddoe VWV, Eriksson JG, Broekman BFP (2017). Influence of maternal obesity on the long-term health of offspring. The Lancet Diabetes \& Endocrinology, 5(1): 5364. doi: 10.1016/S2213-8587(16)30107-3.

Green MJ and Popham F. (2017). Life course models: Improving interpretation by consideration of total effects. International Journal of Epidemiology, 46(3)1057-1062. doi: 10.1093/ije/dyw329.

Guendelman S, Kosa JL, Pearl M, Graham S, Goodman J, Kharrazi M. (2009). Juggling Work and Breastfeeding: Effects of Maternity Leave and Occupational Characteristics. Pediatrics, 123(1): e38-e46. doi: 10.1542/peds.2008-2244.

Han JC, Lawlor DA, Kimm SYS (2017). Childhood obesity. The Lancet. 375 (1737-1748).

Han TS, Hart CL, Haig C, Logue J, Upton MN, Watt GCM, Lean MEJ (2015). Contributions of maternal and paternal adiposity and smoking to adult offspring adiposity and cardiovascular risk: The Midspan Family Study. BMJ Open, 5(11). doi: 10.1136/bmjopen2015-007682.

Hardy R (2015). A life course approach to cardiovascular disease prevention. Future cardiology, 10(2): S20-S31. doi: 10.1016/S1474-5151(11)oo113-7.

Herman DR, TaylorBaer M, Adams E, Cunningham-Sabo L, Duran N, Johnson DB, Yakes E (2014). Life course perspective: Evidence for the role of nutrition. Maternal and Child Health Journal, 18(2): 450-461. doi: 10.1007/s10995-013-1280-3.

Hirko KA, Kantor ED, Cohen SS, Blot WJ, Stampfer MJ, Signorello LB (2015). Body mass index in young adulthood, obesity trajectory, and premature mortality. American Journal of Epidemiology, 182(5): 441-450.

Hirschmugl B, Desoye G, Catalano P, Klymiuk I, Scharnagl H, Payr S, Kitzinger E, et al. (2017). Maternal obesity modulates intracellular lipid turnover in the human term placenta. International Journal of Obesity. Nature Publishing Group, 41(2): 317323. doi: 10.1038/ijo.2016.188.

Howie EK, Brewer A, Brown WH, Pfeiffer KA, Saunders RP, Pate RR (2014). The 3-year evolution of a preschool physical activity intervention through a collaborative partnership between research interventionists and preschool teachers. Health Education Research, 29(3): 491-502.

Isgor Z, Powell L, Rimkus L, Chaloupka F (2016). Associations between retail food store exterior advertisements and community demographic and socioeconomic composition. Health and Place. Elsevier, 39(43-50). doi: 10.1016/j.healthplace.2016.02.008.

Jornayvaz FR, Vollenweider P, Bochud M, 
Journal of Epidemiology and Public Health (2017), 2(3): 267-283

https://doi.org/10.26911/jepublichealth.2017.02.03.08

Mooser V, Waeber G and MarquesVidal P. (2016). Low birth weight leads to obesity, diabetes and increased leptin levels in adults: The CoLaus study. Cardiovascular Diabetology. BioMed Central, 15(1)1-10. doi: 10.1186/s12933-016-0389-2.

Kementerian Kesehatan (2015). Profil Kesehatan Indonesia 2014. Jakarta: Kemenkes.

Koletzko B, Brands B, Chourdakis M, Cramer S, Grote V, Hellmuth C, Kirchberg F, et al. (2014). The power of programming and the earlynutrition project: Opportunities for health promotion by nutrition during the first thousand days of life and beyond. Annals of Nutrition and Metabolism, 64(3-4)187-19. doi: 10.1159/000365017.

Dinas Kesehatan Kota Surakarta. (2014). Profil Kesehatan Kota Surakarta 2014. Surakarta : Dinkes Surakarta.

Kuhle S, Tong OS and Woolcott CG. (2015). Association between caesarean section and childhood obesity: A systematic review and meta-analysis. Obesity Reviews, 16(4) 295-303.

Labresh KA. (2016). Improving outcomes for Noncommunicable Diseases in low- and middle-income countries.

Laurson KR, Lee JA, Gentile DA, Walsh DA, Eisenmann JC (2014). Concurrent Associations between Physical Activity, Screen Time, and Sleep Duration with Childhood Obesity, ISRN Obesity, 1-6. doi: 10.1155/2014/204540.

Lewis RM, Demmelmair H, Gaillard R, Godfrey KM, Hauguel-De MS, Huppertz B, Larque E, et al. (2013). The placental exposome: Placental determinants of fetal adiposity and postnatal body composition. Annals of Nutrition and Metabolism, 63(3):
208-215. doi: 10.1159/ooo355222.

Mamun AA, Mannan M, Doi SAR (2014). Gestational weight gain in relation to offspring obesity over the life course: A systematic review and bias-adjusted meta-analysis. Obesity Reviews, 15 (4): 338-347. doi: 10.1111/obr.12132.

Martin RM, Kramer MS, Patel R, RifasShiman SL, Thompson J, Yang S, Vilchuck K, et al. (2017). Effects of promoting long-term, exclusive breastfeeding on adolescent adiposity, blood pressure, and growth trajectories: A secondary analysis of a randomized clinical trial. JAMA Pediatrics, 171(7): e170698. doi: 10.1001/jamapediatrics.2017.0698.

McDonald SD, Han Z, Mulla S, Beyene J (2010). Overweight and obesity in mothers and risk of preterm birth and low birth weight infants: systematic review and meta-analyses. $\mathrm{Bmj}$, 341(201): c3428c3428. doi:10.1136/bmj.c3428.

Mirkovic KR, Perrine CG, Scanlon KS, Grummer-Strawn LM (2014). In the united states, a mother's plans for infant feeding are associated with her plans for employment. Journal of Human Lactation, 30(3): 292-297. doi: 10.1177/0890334414535665.

Nkrumah J (2017). Maternal work and exclusive breastfeeding practice: A community based cross-sectional study in Efutu Municipal, Ghana. International Breastfeeding Journal. 12(1): 1-9. doi: 10.1186/s13006-0170100-6.

O’Reilly JR, Reynolds RM (2013). The risk of maternal obesity to the long-term health of the offspring, Clinical Endocrinology, 78(1): 9-16. doi: 10.1111/cen.12055.

Ogbuanu C, Glover S, Probst J, Liu J, Hussey $J$ (2011). The Effect of Mater- 
nity Leave Length and Time of Return to Work on Breastfeeding. Pediatrics, 127(6): e1414-e1427. doi: 10.1542/peds.2010-0459.

Paes VM, Ong KK, Lakshman R (2015). Factors influencing obesogenic dietary intake in young children (0-6 years): Systematic review of qualitative evidence. BMJ Open, 5(9): 110. doi: 10.1136/bmjopen-2014-007396.

Pérez-escamilla R, Kac G (2013). Childhood obesity prevention: a life-course framework Childhood obesity prevention: a life-course framework. 2-5. doi: 10.1038/ijosup.2013.2.

Pluymen LPM, Smit HA, Wijga AH, Gehring U, De Jongste JC, Van Rossem L (2016). Cesarean Delivery, Overweight throughout Childhood, and Blood Pressure in Adolescence, Journal of Pediatrics. Elsevier Inc., 179: 111-117.e3. doi: 10.1016/j.jpeds.2016.08.059.

Poston L (2012). Best Practice \& Research Clinical Endocrinology \& Metabolism Maternal obesity, gestational weight gain and diet as determinants of offspring long term health, Best Practice \& Research Clinical Endocrinology \& Metabolism. Elsevier Ltd, 26(5): 627639. doi: 10.1016/j.beem.2012.03.010.

Qiao Y, Zhang T, Liu H, Katzmarzyk PT, Chaput JP, Fogelholm M, Johnson $\mathrm{WD}$, et al. (2017). Joint association of birth weight and physical activity/ sedentary behavior with obesity in children ages 9-11 years from 12 countries. Obesity, 25(6): 1091-1097. doi: 10.1002/oby.21792.

Ramírez A, Bernal O, Rodríguez J, Pinzón JD (2016). Morbidity Due to Obesity, Hypertension and Diabetes II Attributable to Non-Breastfeeding and
Low Birth Weight during the 1000 Days of Life: Estimation of the Population Attributable Fraction. Health, 8(386-401). doi:10.4236/health.2016.85041.

Redsell SA, Edmonds B, Swift JA, Siriwardena AN, Weng S, Nathan D, Glazebrook C (2016). Review Article Systematic review of randomised controlled trials of interventions that aim to reduce the risk, either directly or indirectly, of overweight and obesity in infancy and early childhood, 2438. doi: 10.1111/mcn.12184.

Ahima RS (2014). Childhood Obesity Prevalence, Prevalence, Pathophysiology, and Prevention. Toronto New Jarsey: Apple Academic press.

Robinson M, Crozier SR, Harvey NC, Barton BD, Law CM, Godfrey KM, Cooper C, et al. (2015). Modifiable early-life risk factors for childhood adiposity and overweight: an analysis of their combined impact and potential for prevention. The American Journal of Clinical Nutrition. 101 (368-375). doi: 10.3945/ajcn.114.094268.Am.

Rollins NC, Bhandari N, Hajeebhoy N, Horton S, Lutter CK, Martines JC, Piwoz EG, et al. (2016). Why invest, and what it will take to improve breastfeeding practices?. The Lancet. Elsevier Ltd, 387(10017): 491-504. doi: 10.1016/So140-6736(15)01044-2.

Rutayisire E, Wu X, Huang K, Tao S, Chen Y, Tao F (2016). Cesarean section may increase the risk of both overweight and obesity in preschool children. BMC Pregnancy and Childbirth. BMC Pregnancy and Childbirth.16(1)1-8. doi: 10.1186/s12884-016-1131-5.

Small L, Aplasca A (2016). Child Obesity and Mental Health. A Complex Interaction. Child and Adolescent Psy- 
chiatric Clinics of North America. Elsevier Inc, 25(2)269-282. doi: 10.1016/j.chc.2015.11.008.

Sutharsan R, Mannan M, Doi SA, Mamun AA (2015). Caesarean delivery and the risk of offspring overweight and obesity over the life course: a systematic review and bias-adjusted metaanalysis.13(293-301).

UNICEF, WHO, Word Bank (2014). Levels and Trends in Child malnutrition. Midwifery. 4(96): 90067-4. doi: 10.1016/So2666138.

Wang L, Collins C, Ratliff M, Xie B, Wang Y (2017). Breastfeeding Reduces Childhood Obesity Risks. Childhood Obesity. 13(3): 197-204. doi: 10.1089/chi.2016.0210.

Ward LC, Poston L, Godfrey KM, Koletzko B (2013). Assessing early growth and adiposity: Report from an early nutrition academy workshop on behalf of the earlynutrition academy. Annals of Nutrition and Metabolism. 63(1-2): 120-130. doi: 10.1159/ooo350702.

Weng SF, Redsell SA, Nathan D, Swift JA, Yang M (2014). Estimating Overweight Risk in Childhood From Predictors During Infancy. Pediatrics 132: e414. doi: 10.1542/peds.20123858 .

Weng SF, Redsell SA, Swift JA, Yang M, Glazebrook CP (2012). Systematic review and meta-analyses of risk factors for childhood overweight identifiable during infancy. Archives of Disease in Childhood. 97(12): 10191026. doi: 10.1136/archdischild-2012302263.

Wijnhoven TM, vanRaaij JM, Spinelli A, Yngve A, Lissner L, Spiroski I, Farrugia SV, et al. (2016). WHO European Childhood Obesity Surveillance Initiative: Impact of Type of
Clothing Worn during Anthropometric Measurements and Timing of the Survey on Weight and Body Mass Index Outcome Measures in 6-9Year-Old Children. Epidemiology Research International. 2016 (1-16).

WooBaidal JA, Locks LM, Cheng ER, Blake-Lamb TL, Perkins ME, Taveras EM. (2016). Risk Factors for Childhood Obesity in the First 1,00o Days. American Journal of Preventive Medicine. Elsevier, 50(6): 761-779. doi: 10.1016/j.amepre.2015.11.012.

World Health Organization (WHO) (2016). World Health Statistics SDGs. Geneva: WHO.

(WHO). (2016b). Consideration of the evidence on childhood obesity for the Commission on Ending Childhood Obesity: Report of the Ad hoc Working Group on Science and Evidence for Ending Childhood Obesity. World Health Organization. (1-30). doi: ISBN 9789241510066 .

(2014). Report of the First Meeting of the Ad hoc Working Group on Science and Evidence for Ending Childhood Obesity. World Health Organization. doi: ISBN 978924 1510066.

Yang Z, Huffman SL (2013). Nutrition in pregnancy and early childhood and associations with obesity in developing countries. Maternal and Child Nutrition. 9(1): 105-119. doi: 10.1111/mon.12010.

Zamzani M, Hadi H, Astiti D (2016). Aktifitas fisik berhubungan dengan kejadian obesitas pada anak sekolah dasar. Jurnal Gizi dan Dietik Indonesia. 4(3): 123-128. doi: 10.21927/ijnd.2016.4(3).123-128.

Zheng JS, Liu H, Zhao YM, Li J, Chen Y, Zhu S, Chen H, et al. (2015). Complementary feeding and childhood 
Nudhira et al./ Path Analysis on Life Course Factors Affecting Overweight

adiposity in preschool-aged children in a large Chinese cohort. Journal of Pediatrics. Elsevier Inc, 166(2): 326- 331.e2.doi: $\quad 10.1016 / j . j p e d s .2014 .11 .-$ 010. 